\title{
Utilizing Language Laboratories: Chances and Challenges in Teacher's Perspective
}

\author{
Silfia Asningtias \\ Universitas Negeri Surabaya \\ Surabaya, Indonesia \\ silfiaasningtias@unesa.ac.id
}

\begin{abstract}
To support the teaching and learning of English as a foreign language in Indonesia, language laboratories has been provided by the government in many schools in Indonesia. The purpose are for the students to get exposure of real life language usage by the speakers of English. The worrying trend for further attention that it is neglected and abandoned at some schools. To run an effective language laboratories, four elements should be present, namely the facilities, standard operational procedure, pupils and language lab coordinators. This study aims to unfold the chances and challenges of running the language lab at several secondary school level based on teacher's perspective. First, on how the English language teachers perceive the importance of language lab in process of teaching and learning English. Secondly, to what extent the teachers' have been utilizing the language lab in their teaching, and lastly, what the teacher's views on the use of language lab should be at school. The discussion also will expand on leadership roles in improving the roles of an English language laboratories. The qualitative approach is employed by having classroom observation and interviews with emphasis on the literature review. The findings confirms that teachers highly considered that some language skills will be more effectively taught in language laboratories, however, several obstacle occurs, for instance; the outdated equipment, unskillful teachers to operate the devices, less teaching resources, time allotment and tight schedule among others.
\end{abstract}

Keywords-language laborary; challenges; teacher's perspective

\section{INTRODUCTION}

Good communication skills are indispensable for English language learner. Those who have been studying the language for many years aim to be able to speak fluently and eloquently. With the four skills of language elements to be practice, the needs to have instruments to assist learners is expected. Language laboratory plays an important role in the teaching and learning process. As it is a technological aid for learning, it has a number of advanced facilities that can help a student to learn a language with proficiency to communicate. It has become inevitable in today's context but, at the same time, it poses certain challenges. This article attempts to highlight the significance of the language laboratory and its challenges imposed the teaching and learning process on teacher's belief.

In Indonesian context, English is taught as early as first grade of Elementary school level at some schools, although in general, the subject is trained at the fourth grade level. In reality, students who have been learning English since their primary school, exposed difficulties in speaking English fluently. This problem, somehow, is due to the little practice they performed during their lessons; even though the curriculum is very rich of these components. Therefore, it is assumed that teaching and learning in language laboratory can be an alternative solution to attract students' attention so that they can retain the language mastery better. Walker \&White [1] assert that foreign language learning will be more effective when students are exposed to the environment in which the target language is utilized. With the exposure of technology in many aspects of our life, in which English language learning was enforced naturally to the use of media, language lab can greatly help students to learn a language of their own choices and pace.

Language laboratory used to become a facility that schools boast to the stakeholder that it would facilitate the learning of foreign language better. However, recent years, that perspective has changed and many schools re-asses the strength and weakness of having the language lab, and some has refunctioning the place into regular classroom. With the outdated devices and the high cost of purchasing new tools as well as maintanes, schools management believe that the language lab is no longer effective to support the teaching and learning. Not to mention on the limited time allotment for students to use the language lab. With the common use of smartphones and other enhanced technology devices at the students' fingertips, schools believe it is no longer essentials to have the teaching and learning activities in the laboratories since you can bring the world in the classroom by using the internet. It is assumed that conducting the listening and speaking activities in the classroom works the same effective as having the class in the language lab. Having said that, it is crucial to find out on how the English language teachers perceive the importance of language lab in process of teaching and learning English. With the limited workshop teachers get on how to conduct their teaching in language lab, it is essential also to dig up on to what extent the teachers' have been utilizing the language lab in their teaching, and lastly, what the teacher's views on the use of language lab should be at school.

\section{LITERATURE REVIEW}

The Language Laboratories (LL) support teachers in delivering foreign language through audio or audiovisual. It has gone through many development stages over the years. The type of language laboratories commonly used are: (1) Conventional Laboratory, (2) Lingua Phone Laboratory, (3) Computer Assisted Language Laboratory (CALL), and (4) Multimedia Hi-Tech Language Laboratory. Most schools, either in secondary and higher education are well furnished with the high technology language laboratories that can also be 
referred as language resource center, multimedia center, CALL Labs that basically allow teachers to interact with students in computerized system [2] [3]. In addition, language laboratories can be used for teaching a number of language efficiently, as Richards [4] asserts that sensibility towards sounds and rhythm of foreign language can only be obtained through the best sample of spoken language, and this is the foundation of language laboratory function.

Managing language lab requires a well-rounded administrator that can manage the schedule of users, troubleshooting and maintenance and helpdesk, thus the role of language lab coordinator is undeniably essentials [5]. As Davis [6] argues that it is more beneficial to invest on human development rather than the technology. Even with the most updated technology devices installed in the language lab, without a reliable man power to operate, it would be over expectation that the device itself can enhance language learning. With a proper and continuous training of teachers and coordinator, it is expected that the language lab will gain its full potential. Studies on teacher's role as language lab administrator shows that many of the language teachers have proper training in operating language lab in their precinct, however, the confidence in working with the devices and skills in trouble shooting which is badly needed [7] [8].

In many studies in language lab regarding responds from students in the teaching and learning language show positive trends. Lokmaciouglu [9] in his observation on whether language lab is actually abandoned or it is finding new direction towards a better usage, found that students feel the need to study in language lab since it raise their motivation and enhance their study skills. The concept of language laboratories might shift from traditional to multimedia and high technology one, however, the core of learning in a language lab atmosphere remain the students' preference. Similar study conducted by Dunkel [10] that students feels more confident and motivated when they can learn in their own pace in language laboratories. The language lab has given sense of comfort as they can work on their task on their individual basis, without feeling insecure of being in competition. Having language lab administrator or language teachers who have confident and adequate skills to operate would be the most essential needs to make successful learning in language laboratories.

Reflecting on the previous studies that highlight the use of language laboratories in secondary school level from both laboratories administrator and students' perspective, this study attempts to investigate the teacher's perspective in managing their lesson in language laboratories. The discussion is on both their role as a teacher and as language lab administrator.

\section{METHODOLOGY}

\section{A. Setting and Participants}

This paper reports on interview and observation conducted with 10 English language teachers in several secondary schools in Surabaya which has language laboratories in their facilities. These teachers have been teaching for more than 10 years in the same schools and have experienced in utilizing the language laboratories existed.

\section{B. Data Collection Analysis}

To responds to the research questions mentioned, qualitative research method is employed. Both interview and classroom observation result are elaborated in the descriptive way. In the interview, the researcher use both closed ended and open ended questions to give teachers opportunity to add comprehensive detail on their feedback. In addition, unscripted questions are presented during the interview to support the elaborated answers.

\section{RESULTS}

Language Laboratory (LL) has been utilized by language teachers to enhance their teaching of English by emphasizing the exposure of the target language. Many English teachers feels confidence in teaching English in the language lab, however, they are a number of them who have less selfassurance in conducting their English class in the lab. Apart from the many advantages that is agreed of language laboratories, based on the observation and interview, there are some challenges that inhibit the teachers to optimize the language lab owned by the school.

On research questions of how the English language teachers views about the needs of utilizing the language laboratories in their teaching and learning process, most respondents emphasize that it is crucial for students to get exposure to the authentic use of language by the native speakers of English. With the enhanced use of mobile phone technology and affordable internet access, students are exposed to many website with English as the language of instruction. However, this does not less the role of guided lesson on listening and speaking activities to improve their language skills. To emphasis, teachers believe that when students are situated in language lab during the listening activities class, they will take advantage by having a secure environment with less disturbance on noises, which resulted in better focus and concentration on the main features being discuss in the tape. In addition, teachers believe that having their lesson conducted in the language laboratories, it will provide students ideal environment to carefully listen to conversation or utterances, although real life activity will be less likely similar. As the pupils are in the learning stages, the ideal environment help them in process of acquiring the language. From the respondents, the answers are unanimous that conducting teaching and learning process in the language laboratories will improve students' proficiency.

To respond on their activities in the language lab, many teachers were upfront in regards to the needs to have Lab assistance to run the device or managing the tools. Most of the teachers are senior in terms of age and employment period, therefore they admit that they have limitation in working with technologies. During the class session at language lab, many times they have to encounter with machine breakdown, malfunction of one or two devices, which is emotionally and time consuming. And this situation is not effective when the class session at language lab is supposed to be 50 minutes, and the breakdown will take up the teaching time. Troubleshooting 
skills is the one required to support the teaching and learning in language lab. They insist that there should be laboratory assistance to support their teaching session. Otherwise, the teacher will spend too much time in troubleshooting. Concerning the upgrading workshop to operate the lab devices, it is consider necessary, however, they believe that assistance is still required to support and manage teaching and learning process. Some of the respondent mention that they already got the training to work with the language lab devices, nevertheless support system is still needed.

As teachers believe that it is necessary to have the students learn English in ideal environment, in which they can listen to native speakers of English and practice the language with less of distraction, many of them suggest that there are several aspects to be improved. First, the time allocation in using the laboratories. The curriculum stated that English subject time allotment is 4 hours per week with 50 minutes per hour. This situation is stressful for the teachers as the demand is so high, listening is part of national examination, and the time allotment is so limited. Practically, teachers can only do one session per week to cover the listening and speaking activities in the language lab. From the interview, they stated that this is not enough, taking into consideration the students mobility and the troubleshooting. They demanded to have at least 2 hours session in the language laboratories to conduct listening comprehension lesson. Second, update of the tools or devices. Since the facilities were built, many times it does not come with the funding to renew or update the devices. There is limited funding or so to say even not at all funding to rejuvenate the devices, such as from Cassette player or CD player to computerized and digital version. This is essential to be taken into consideration as the technologies comes with consequences in funding. When the devices is not supported, it is challenging to teach. For example, it is not easy to get the carbon cassette to play in player. And lastly is teaching material for students learning. Internet has provided unlimited resources to teach and learn English for us to utilize for free. The challenges are on the skills to work on internet to get the appropriate teaching and learning resources, especially for the seniors' teachers.

\section{DISCUSSION AND SUGGESTIONS}

From the above findings, we can draw conclusion about the use of language laboratory in the teaching and learning English from the teacher perspectives are all positive. That learning foreign language will be more effective when it is conducted in supported learning environment, in this case is language laboratory. However, from the interview and observation during the research, there are aspects of utilizing language laboratories that needs to be put into consideration. First, the concept of language lab nowadays needs to shift from the traditional to the modern one. Classrooms can be shaped into language lab with proper equipments. The notion is not about abandoning or discarding the language laboratories facility, but optimize the teaching and learning activity in the classroom by bringing the language lab to the students. Secondly is about the needs for effective training for language lab administrator and language teachers should be highlighted [11]. No matter how cutting edge the technology, the lab usage is affected directly by the lab administrator or teacher's skills and confident. Lastly, class management regarding time allocation of the learning to be conducted in language lab is heavily considered as success factor in our study.

In the light of finding, having modern lab is undoubtedly important to support effective language teaching and learning process, nevertheless, the utmost important is on the confidence and competence of language teachers to conduct their lesson in the language laboratory to enhance learning.

\section{ACKNOWLEDGMENT}

The write would like to express gratitude to the respondents of this study who have been positively open regarding their teaching challenges at their respective schools. She would like to also to thank her colleagues for feedback and comments to the manuscript.

\section{REFERENCES}

[1] A. Walker, and G. White, "Technology enhanced language learning". Oxford University Press, 2013.

[2] C. Alexander, "Language labs: An overview of trends," Teaching English with Technology Journal, vol. 7, pp. 1-16, 2013.

[3] M. Marzuki, "Managing an effective English language laboratory in a Polytechnic," Studies in English Language and Education, vol. 1, pp. 106$11,2014$.

[4] J. Richards, "Approaches and methods in language teaching," Cambridge: Cambridge University Press, 2001.

[5] C. Alexander, "Humanising management software," Teaching English with Technology Journal, vol. 8, pp. 1-17, 2008.

[6] R. Davis, "Retooling perspectives on technology's role in language education," Studies in Self-Access Learning Journal, vol. 2, pp. 212-218, 2011.

[7] K. D Hafiz, "An investigation into CALL in English language teaching through language laboratory," IOSR Journal of Humanities and Social Science (IOSR- JHSS), vol. 6, pp. 08-14, 2013.

[8] S. Hashmi, "Need of an English language laboratory in engineering universities," IJCSN International Journal of Computer Science and Network, vol. 2, pp. 08-10, 2013.

[9] S. Lokmacioglu, "Language labs: Dying or evolving?," Procedia-Social and Behavioral Sciences 199, pp. 65-72, 2015.

[10] P. Dunkel, "Implications of the CAI effectiveness research for limited English proficient learners, computers in schools", vol. 7, pp. 31-52, 2001.

[11] L. Coles, A. Richardson, and J. Tuson, "Integrating information and communications technology in professional practice: an analysis of teachers' needs based on a survey of primary and secondary teachers in Scottish schools," Journal of Information Technology for Teacher Education, vol. 9, pp. 1-16, 2000. 